\title{
Marfan syndrome, dissecting aneurysm of the aorta, and pregnancy
}

\author{
H. C. MOORE \\ From the Rotunda Hospital Laboratory, Dublin
}

SYNOPSIS A patient with the Marfan syndrome died suddenly from aortic rupture and dissection in the early puerperium of her second pregnancy. Although the association of the Marfan syndrome and pregnancy is extremely rare, the case reported here being only the fifth on record, the concurrence of dissecting aneurysm or aortic dissection with pregnancy is more frequent. Furthermore it is accepted that aortic dissection in young women below the age of 40 is more common in the pregnant than those not pregnant. The cause of the enhancing effect of pregnancy is unknown but is thought to be endocrine since the stability of connective tissue can be influenced by hormones, particularly the sex steroids.

An unusual feature of the present case is the florid inflammatory reaction in the adventitia of the aorta, not specifically related to pregnancy or to the Marfan syndrome, and it is assumed that in this patient the congenital defect of connective tissue assumed to be the basis of the Marfan syndrome is associated with an acute collagen change or necrosis, possibly illustrating a link between the heritable disorders of connective tissue and the diffuse collagen disease.

\section{CASE REPORT}

J.H. (48355/54865), aged 24 years, had a normal pregnancy in 1961. In this her second pregnancy a spondylolisthesis of the fifth lumbar vertebra was discovered, but no other abnormality was found. The Wassermann reaction was negative. She had a normal delivery on 8 June 1962.

Her blood pressure during pregnancy had been normal apart from one occasion, on the day before delivery, when the blood pressure was recorded as $174 / 110 \mathrm{~mm} . \mathrm{Hg}$. During the puerperium her blood pressure varied between $150 / 160 \mathrm{~mm} . \mathrm{Hg}$ systolic and $80 / 100 \mathrm{~mm} . \mathrm{Hg}$ diastolic. She was discharged on 14 June apparently quite well. Two days later she suddenly felt unwell, became unconscious, and died about an hour and a half later.

\section{NECROPSY REPORT}

The body was slight and the height $5 \mathrm{ft} .1 \mathrm{in}$. The fingers were very long and pointed and considered to be characteristic of arachnodactyly. The thoracic cage, skull, and palatal arch were normal, and the sclerotics of normal appearance.

The significant findings were those of the heart and aorta. The pericardial sac was distended with blood clot but the heart was of normal size and structure. The ascending aorta showed three tears. The largest, postero-lateral on the right and $1 \mathrm{~cm}$. above the valve, was transverse and about $1 \mathrm{~cm}$. across. The second tear, $1 \mathrm{~cm}$. above the valve, was posterior, vertical, about $1 \mathrm{~cm}$. in length, and the third, postero-lateral on the left, was transverse, $\frac{1}{2} \mathrm{~cm}$. in extent and $1 \frac{1}{2} \mathrm{~cm}$. above the valve. The aorta was split behind the first tear and dissected by blood clot into the pericardial sac. Dissection distally was found as far as the iliac arteries. There was no gross dilatation of the aortic ring nor were cushion-like thickenings of the aortic cusps found.

The only other significant finding was the spondylolisthesis of the fifth lumbar vertebra.

HISTOLOGY Histological descriptions are restricted to the aorta.

The intima showed a slight focal thickening due to numerous macrophages filled with lipoid.

The split in the wall of the aorta was in the outer third of the media. At this site and elsewhere there were scattered focal accumulations of mucoid material staining pale blue in conventional preparations with haematoxylin and eosin and showing metachromasia with toluidine blue. There was no cellular reaction around these accumulations and elastic tissue was absent. 
Blood clot was found in the split and, particularly in the proximal aorta; it was lined by a thick layer of fibrin sometimes showing early organization. In other sites endothelialization of the wall of the split was apparent.

In all sections the elastic pattern in the media was bizarre. The fibres were irregularly aligned, appeared broken and frayed and in some areas were tangled together in masses. In other areas elastic tissue was absent and the internal elastic lamina, for example, showed extensive gaps. Small haemorrhages were found in the media both at the site of the split and elsewhere and were associated with a cellular infiltration of mononuclear cells but this association was by no means invariable.

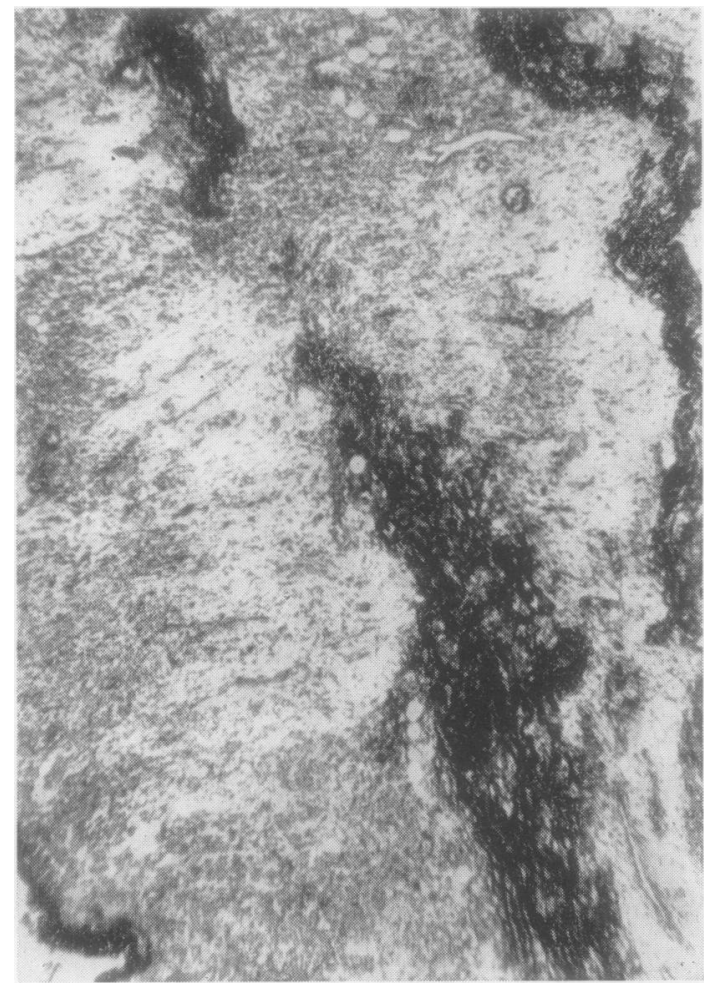

FIG. 1. Section from the margin of the aortic split (lower left hand corner) across the adventitia showing the bands cf fibrin (black). Picro Mallory $\times 60$.

The grossest histological change was found in the adventitia and consisted mainly of a florid cellular reaction most marked in the ascending aorta in the region of the tears, less so in the descending aorta and almost absent in the abdominal aorta although here, as noted previously, the wall was split. In the sections of the proximal aorta the cellular infiltration extended from the adventitia to the fatty connective
FIG. 2. Section from the margin of the aortic split across the adventitia showing the florid inflammatory reaction $\overline{0}$ Haematoxylin and eosin $\times 60$.

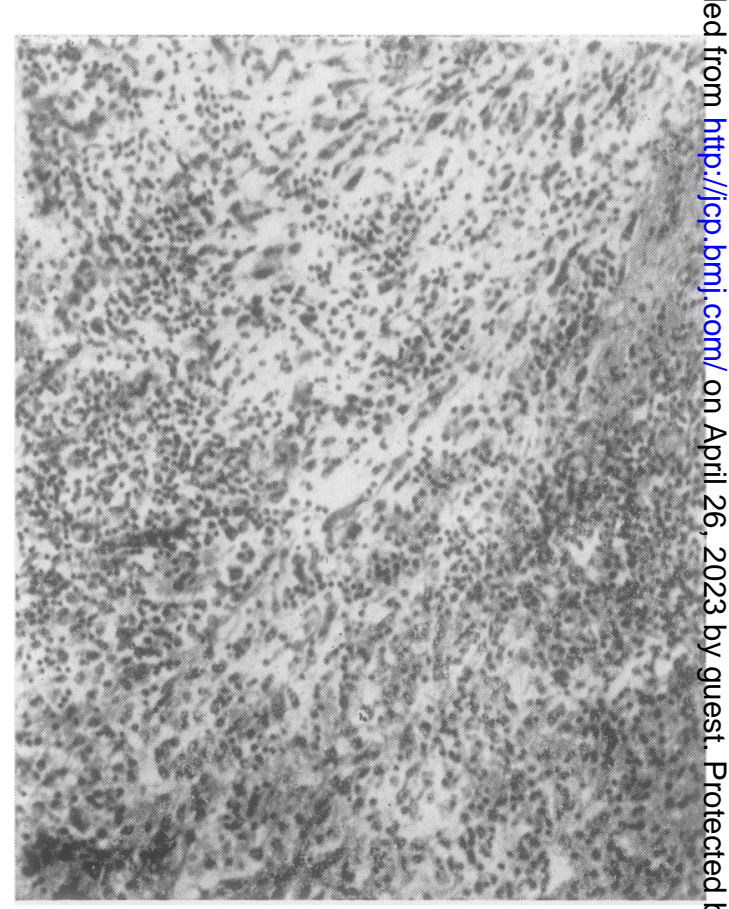

FIG. 3. Cellular reaction in the adventitia. Haematoxyline and eosin $\times 165$. 
tissue between the aorta and the myocardium but the myocardium itself was not involved in this process nor did it show any other celullar reaction.

Two processes appeared to be involved. First there were one or more layers of organizing and hyalinized fibrin, lying parallel to and below the thick fibrin wall of the split, presumably indicative of repeated haemorrhages (Fig. 1). The second process was the gross cellular infiltration diffusely involving all parts of the adventitia including but extending beyond the area of fibrin deposition (Figs. 2 and 3), and was in certain fields focal in character; lymphocytes, plasma cells, basophil histiocytes, multinucleated giant cells, and, most marked of all, eosinophil leucocytes surrounded isolated pieces of collagen (Fig. 4), which stained deeply with eosin and with acid fuschin and gave none of the staining reactions for fibrin by Mallory's phosphotungstic-acid-haematoxylin method nor by the Gram-Weigert method. Pigmented macrophages were not found in these areas.

In a section of the thoracic descending aorta, an intercostal artery showed medial calcification and gross intimal thickening with mucoid change.

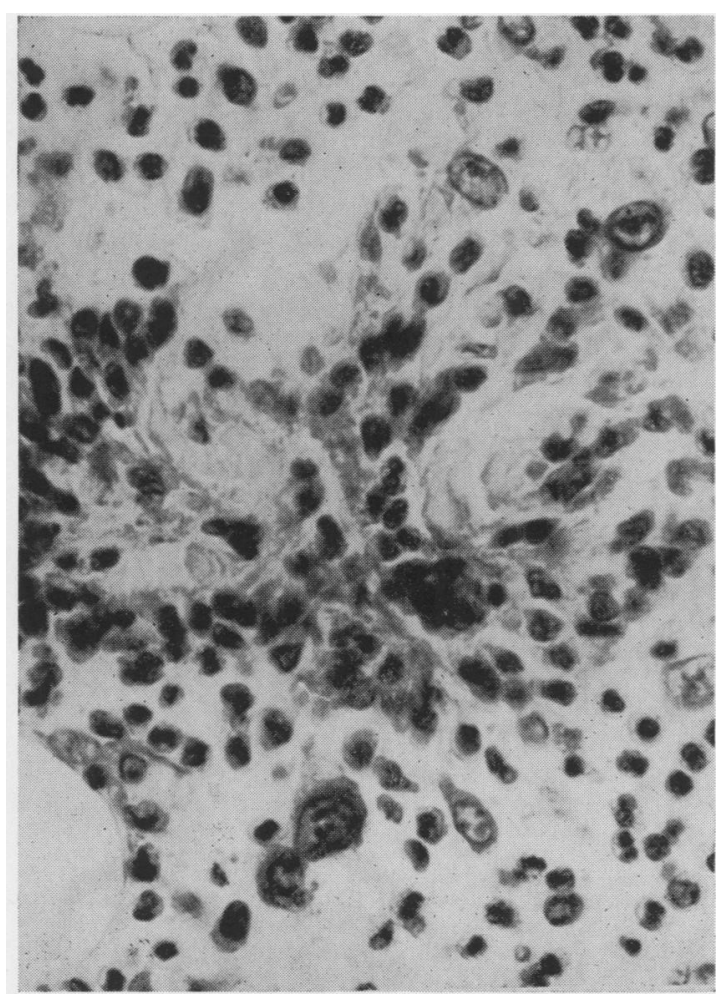

FIG. 4. Collagen fragments with the surrounding cellular reaction in the adventitia. Haematoxylin and eosin $\times 650$.

\section{DISCUSSION}

Two points are of interest, the histology of the aorta and the association of pregnancy and aortic dissection.

HISTOLOGY OF THE AORTA The lesions of the aortic media in the present case are the same as those classically described as Erdheim's cystic medionecrosis affecting the elastic tissue (Braunstein, 1963), and those manifest as an increased metachromasia of the ground substance, either an absolute or relative increase in the acid mucopolysaccharides, hyaluronic acid, or chondroitin sulphate C (MacLeod and Williams, 1956; Raekallio, 1958; Manley and Kent, 1963; Manley, 1964).

The finding, however, of a gross inflammatory reaction in the adventitia is at variance with all or almost all, recorded instances of aortic rupture or dissection. The recent reports of MacLeod and Williams (1956), Marvel and Genovese (1951), Sloper and Storey (1953), Uyeyama, Kondo, and Kamins (1947), Whittaker and Sheehan (1954), Hickey (1953), Braunstein (1963), and the reviews of the histology of the aorta in Marfan's syndrome by McKusick (1960) and Sinclair, Kitchin, and Turner (1960) either state or imply that there is no adventitial inflammatory change. The report of Novell, Asher, and Lev (1958) is the only one I have found since Shennan's (1934) that describes haemorrhage and neutrophil infiltration in the adventitia at the site of the aortic split. In four out of Shennan's series of 15 cases, changes resembling rheumatic aortitis were found and in these the vasa vasorum showed an endarteritis similar to that described in the present report. It is apparent that similar inflammatory changes had been observed before and Shennan refers to Rokitansky's papers $(1839,1844,1852 \mathrm{a}, 1852 \mathrm{~b}, 1856)$ in which it is suggested that there is one form of dissecting aneurysm in which the adventitia is thick, vascular, and in a condition of chronic inflammation. Shennan implies, although does not actually state, that these lesions are due either to syphilis or to rheumatism. His four patients were two men, aged 75 and 49, and two women aged 55 and 62 years, and clearly the adventitial reaction has no specific relation with pregnancy. Shennan's main conclusion, like all subsequent authors', is that the medial changes are the most important, and he does not enlarge further on the inflammatory changes nor on any concept derived from them.

Although the florid adventitial inflammation described here is rather similar to that described by Baggenstoss and Saphir (1960) as rheumatic aortitis there is no other suggestion that in the present case 
acute rheumatism coexisted with the Marfan syndrome. It seems reasonable to assume, however, that in this patient there was a primary congenital defect of connective tissue associated with an adventitial collagen change or necrosis. In this way the present case may be regarded as illustrating a possible link between the heritable disorders of connective tissue and the diffuse collagen diseases.

The most important details of the present case and four other examples of Marfan's syndrome and pregnancy are given in Table $I$. The cause of death in each was aortic rupture and dissection and the question arises as to whether pregnancy is a contributory factor. Schnitker and Bayer (1944) found that of a total of 141 fatalities in patients under 40 due to dissecting aneurysm, 49 occurred in young women and of these 24 were pregnant at the time of the fatal rupture. This proportion, $50 \%$ approximately, is supported by Mandel, Evans, and Walford (1954), who found that of 70 reported instances of dissecting aneurysm in young women, 37 were pregnant or in the puerperium at the time of rupture. Of 11 patients for whom the time of death was given, six died at between 7 and 9 months' gestation, three at $2 \frac{1}{2}$ to 5 months' and, two in the puerperium. In Table I, two patients experienced attacks during gestation one of which was fatal. The $50 \%$ incidence of pregnancy in fatal cases due to dissecting aneurysm is to be compared with the figure for the proportion of women pregnant at any time, excluding early miscarriage. This figure for Dublin for the age group 20 to 39 years is 134 per 1,000 women and for the age group 15 to 44 years 92 per 1,000 women. On these grounds it must be accepted that pregnancy is a predisposing factor in aortic rupture or dissection when, presumably, the characteristic aortic lesion is present. It is not suggested that medial necrosis or other aortic lesions are more common in pregnancy or that the lesions are in any way different.

An opposing view that pregnancy is not an enhancing factor in aortic rupture and dissection is based on the effects of the association of pregnancy, and coarctation of the aorta. In this association there is a low incidence of aortic rupture and dissections to judge from its occurrence in only three of 395 patients reported by Kinney, Sylvester, and Levine,(1945), and furthermore the overall mortality of coarctation of the aorta and pregnancy at $9.5 \%$ is not greater than the figure for the non-pregnane (Goodwin, 1958). However, in Goodwin's seriespo of 13 fatal instances of pregnancy with coarctation w of the aorta, aortic rupture accounted for half, that is, double the overall incidence of this cause of death in all cases of coarctation of the aorta.

It would appear therefore that in patients with coarctation of the aorta, aortic dissection is morew likely to occur in the pregnant than in the nonpregnant but this increased hazard does not increase the overall mortality, since patients withr coarctation of the aorta die from many other causes which may not be affected by pregnancy.

The cause of the increased incidence of aortic rupture and dissection in pregnancy is conjectural $\tilde{Q}^{\circ}$ The phenomenon is not related to the hormone relaxin (McKusick, 1960) but there is a possible relationship with the sex steroids. For example Zachariae (1958) concluded that in the rabbitg oestrogens induce the formation of large quantities. of acid mucopolysaccharides in the stroma ans glands of the endometrium and that this effect is blocked by progesterone. Furthermore, in experi-

TABLE 1

CLINICAL AND POST-MORTEM DETAILS OF FATAL CASES OF MARFAN'S SYNDROME AND PREGNANCY

Author and Date

\begin{tabular}{|c|c|c|c|}
\hline & \\
\hline & $\begin{array}{l}\text { Age } \\
(y r .)\end{array}$ & Parity & Onset and Date of Death \\
\hline $\begin{array}{l}\text { Lindeboom and Bouwer } \\
\text { (1949) }\end{array}$ & 24 & 1 & $\begin{array}{l}\text { At } 7 \text { months' gestation complained } \\
\text { of pain cardiac area (B.P. } 160 / 90 \\
\text { mm. } \mathrm{Hg} \text { ) } 24 \text { hours later, cyanosed, } \\
\text { shocked and died }\end{array}$ \\
\hline $\begin{array}{l}\text { Husebye, Wolff, and } \\
\text { Friedman (1958) }\end{array}$ & 30 & 3 & $\begin{array}{l}\text { At } 22 \text { weeks' gestation substernal } \\
\text { pain with recurrences at } 25 \text { and } 29 \\
\text { weeks. Section and survived. Died } \\
10 \text { months after delivery }\end{array}$ \\
\hline $\begin{array}{l}\text { Novell, Asher, and Lev } \\
\text { (1958) }\end{array}$ & 24 & 3 & $\begin{array}{l}\text { Normal delivery at term. Eleven days } \\
\text { after severe substernal pain and } \\
\text { died in one day }\end{array}$ \\
\hline $\begin{array}{l}\text { Borglin and Bach } \\
\text { (1961) }\end{array}$ & 23 & 1 & $\begin{array}{l}\text { Normal pregnancy and delivery, } \\
\text { after blood pressure not elevated, } \\
\text { section at } 37 \text { weeks. Died nine weeks } \\
\text { after delivery after three days' illness }\end{array}$ \\
\hline Moore (present case) & 24 & 2 & $\begin{array}{l}\text { Normal delivery, blood pressure } \\
\text { elevated }(174 / 110 \mathrm{~mm} \text {. Hg) two days } \\
\text { before delivery. Died suddenly } \\
\text { eight days after delivery }\end{array}$ \\
\hline
\end{tabular}
eight days after delivery
Post-mortem Details

Cause of Death Associated Findings

Dissecting aneurysm aorta

as far as renal artery

Renal cortical necrosis arachnodactyly

Dissecting aneurysm aorta, Tall $(167 \mathrm{~cm}$.$) , dorsal$ dilatation aortic ring

Dissecting aneurysm aorta, haemopericardium

Dissecting aneurysm aorta

Dissecting aneurysm aorta, Arachnodactyly, haemopericardium spondylolisthesis kyphosis, winged scapula, genu valgum, pes planus, $\bullet$ arachnodactyly Arachnodactyly,
kyphoscoliosis, coarctation of aorta Tall $(182 \mathrm{~cm}$.), arachnodactyly, pectus excavatum 
mental lathyrism in rats (Ponseti and Baird, 1952), produced by feeding sweet pea meal, the condition is characterized by kyphoscoliosis, hernia, and dissecting aneurysm. The toxic factor is B (YLglutamyl) aminopropionitrile (Angevine, 1959). It has been found that such lesions are more frequent in males than in females and that the low incidence in females can be raised to that of the male by the simultaneous administration of androgens (Wajda, Lehr, and Krukowski, 1957). Progesterone has androgenic properties and might therefore be implicated in the occurrence of aortic dissection in human pregnancy.

Accepting, therefore, that the stability of connective tissue and ground substance is influenced by sex hormones, it is possible that hormonal changes during pregnancy could alter the connective tissue or ground substance of the aortic wall thereby increasing the risk of rupture and dissection.

I would like to thank the Medical Research Council of Ireland for their continued support, Mr. M. D. McCarthy, Director of the Central Statistics Office, Dublin, for data on the incidence of pregnancy in the population, and to all my colleagues of the Rotunda Hospital and laboratory for their help.

\section{REFERENCES}

Angevine, D. M. (1959). In Modern Trends in Pathology, edited by D. H. Collins, p. 56. Butterworth, London.
Baggenstoss, A. H., and Saphir, O. (1960). In Pathology of the Heart, 2nd ed., edited by S. E. Gould, pp. 643-695. Thomas, Springfield, Illinois.

Borglin, N. E., and Bach, G. (1961). Acta obstet. gynec. scand., 40, 271.

Braunstein, H. (1963). Circulation, 28, 1071.

Goodwin, J. F. (1958). Lancet, 1, 16.

Hickey, M. D. (1953). J. Irish med. Ass., 32, 157.

Husebye, K. O., Wolff, H. J., and Friedman, L. L. (1958). Amer. Heart J., 55, 662.

Kinney, T. D., Sylvester, R. E., and Levine, S. A. (1945). Amer. J. med. Sci., 210, 725.

Lindeboom, G. A., and Bouwer, W. F. (1949). Cardiologia (Basel), $15,12$.

McKusick, V. A. (1960). Heritable Disorders of Connective Tissue, 2nd ed., pp. 42-134. Mosby, St. Louis.

MacLeod, M., and Williams, A. W. (1956). Arch. Path., 61, 143.

Mandel, W., Evans, E. W., and Walford, R. L. (1954). New Engl. J. Med., 251, 1059.

Manley, G. (1964). J. clin. Path., 17, 220.

, and Kent, P. W. (1963). Brit. J. exp. Path., 44, 635.

Marvel, R. J., and Genovese, P. D. (1951). Amer. Heart J., 42, 814. Novell, H. A., Asher, L. A. Jr., and Lev, M. (1958). Amer. J. Obstet. Gynec., 75, 802.

Ponseti, I. V., and Baird, W. A. (1952). Amer. J. Path., 28, 1059.

Raekallio, J. (1958). Arch. Path., 66, 733.

Rokitansky, C. von (1839). Schmidts Jb. ges. Med., 24, 30.

(1844). Handbuch der pathologischen Anatomie, vol. 2, p. 602. Braumüller and Seidel, Vienna.

- (1852a). Manual of Pathological Anatomy, vol. 4, p. 314. Sydenham Society, London.

- (1852b). Ueber einige der wichtigsten Krankheiten der Arterien (Repr. from Denkschr. Akad. Wiss., Wien, 4, 1). K.k. Hof- u. Staatsdruckerei, Vienna.

- (1856). Lehrbuch der pathologischen Anatomie, 3rd ed., vol. 2, p. 343. Braumüller, Vienna.

Schnitker, M. A., and Bayer, C. A. (1944). Ann. intern. Med., 20, 486.

Shennan, T. (1934). Spec. Rep. Ser. med. Res. Coun. (Lond.), 193, 58.

Sinclair, R. J. G., Kitchin, A. H., and Turner, R. W. D. (1960). Quart. J. Med., 29, 19.

Sloper, J. C., and Storey, G. (1953). J. clin. Path., 6, 299.

Uyeyama, H., Kondo, B., and Kamins, M. (1947). Amer. Heart J., 34, 580.

Wajda, I., Lehr, D., and Krukowski, M. (1957). Fed. Proc., 16, 343.

Whittaker, S. R. F., and Sheehan, J. D. (1954). Lancet, 2, 791.

Zachariae, F. (1958). Acta endocr. (Kbh.), 29, 118. 